\title{
A Study of the Strategic Responses of Turkish Airline Companies to the Deregulation in Turkey
}

\author{
Gamze Orhan (Corresponding author) \\ Department of Aviation Management \\ Faculty of Aeronautics and Astronautics \\ Anadolu University, Eskisehir, Turkey \\ Tel: 90-222-321-3550 / 6962 E-mail: gozsoy@anadolu.edu.tr \\ Ender Gerede \\ Department of Aviation Management \\ Faculty of Aeronautics and Astronautics \\ Anadolu University, Eskisehir, Turkey \\ Tel: 90-222-321-3550 / 6966 E-mail: egerede@anadolu.edu.tr
}

Received: August 30, $2013 \quad$ Accepted: September 19, $2013 \quad$ Published: October 1, 2013

doi:10.5296/jmr.v5i4.4201

URL: http://dx.doi.org/10.5296/jmr.v5i4.4201

\begin{abstract}
Turkey opened up its domestic airline market to competition via deregulation in 2003. Thus, new airline companies had the chance to enter the domestic market in which only one airline was previously operating. The aim of this study is to reveal the strategic responses given by the existing and new airline companies in the domestic market which resulted following deregulation. The research findings show that to some extent competition has been brought into airline market in Turkey, Turkish airline companies have created different strategies in this competitive environment, they have tried to position themselves in terms of Porter's competitive strategies and, under the concept of these strategies, they have started to use new strategic tools.
\end{abstract}

Keywords: Strategic responses, Competitive strategies, Deregulation, Turkish airline companies. 


\section{Introduction}

Studies conducted in the deregulated airline markets show that the most significant outcome of deregulation is an increase in competition (Brueckner and Pels, 2007; Doganis, 2005; Hooper, 1998; Kahn, 1988; Morrison and Winston, 1986; Sinha, 2001) and that airline companies give strategic responses to this change (Brueckner and Pels, 2007; Chang and Williams, 2002; Doganis, 1994; Douglas and Cunningham, 1992; Goll et al., 2006). In accordance with Porter's competitive strategies, airline companies have started to position themselves in a clearer way and implement these strategies more consciously. A significant outcome of deregulation in this context is the fact that the cost leadership strategy from Porter's competitive strategies is now visible in air transportation. Deregulation has ensured that all the restrictions on market entries and market exits, pricing, capacity offered, mergers and acquisitions are removed, so that airline companies are liberated as they will make decisions on these issues that will have an impact on their production output; thus the applicability of competitive strategies is ensured.

Deregulation has brought similar impacts and outcomes throughout the world and Turkey followed a similar path after 2003. At different time intervals after this date, eight other carriers entered this market where there used to be only one carrier. As a result of the fact that some airline companies resigned from the market, there are, as of December 2011, six airline companies in addition to Turkish Airlines in the market. After deregulation in 2003, there has been a sudden increase in domestic airline passenger traffic and, by the end of 2004, passenger traffic increased by $58.1 \%$ (dhmi.gov.tr). Turkish Airlines' sub-brand AnadoluJet also created a significant impact in the market. All these developments are proof that along with deregulation, the Turkish domestic airline market has entered into a new process and that there is a need to conduct research into the domestic airline market. Thus, it is now important to conduct research regarding the impact of deregulation on competition in the Turkish domestic airline market and on the kinds of competitive strategies developed. In this study, within this context, we are seeking answers to questions such as how the deregulation affected competition in the market, how Turkish airline companies reacted to deregulation of the market, what sort of strategic competitive tools they started to use and whether they implement a mindful competitive strategy by associating these tools with Porter's competitive strategies or not.

\section{Deregulation and Competition in Airline Transportation}

\subsection{The Deregulation Process}

Deregulation in airline transportation suggests that restrictive regulations that organize airline transportation are either alleviated or totally annulled and that state's interference in airline transportation activities are reduced. The issues, such as market entry and market exit, pricing, capacity offer, and mergers and acquisitions between operators are decisions that impact carriers' strategies, competitive tools and outcomes and they have been subject to strict regulations for many years. It has traditionally been an individual country's aviation authority that decides which airline is to operate between two cities, at what frequency and capacity, on which days and at what time, with what fares and under what conditions to resign from these 
markets. Thus, the aim was to keep competition under control, form a 'regulated competition', protect the industry and create public benefit (Sinha, 2001). However, then came the 1960's and 1970's when this regulatory system became a target for criticism. Mainly in the USA, but also in many other countries, academic economists undertook studies on this issue (Doganis, 2002; Douglas and Miller, 1974; Jordan, 1979; Kahn, 1971; Keeler, 1972; Levine, 1965; Stigler, 1971; Wilson, 1990) and postulated that highly restricted airline transportation brings negative outcomes, contrary to expectations. On top of this came public pressure and following the 1980's, airline transportation entered a new phase with an emerging tendency to deregulation that first started in the USA.

The USA was the first country to deregulate their airline market with the 'Airline Deregulation Act' that was signed into law in 1978, followed by the EU that undertook this gradually after 1987 (Doganis, 2005; Schnell, 2003; Williams, 2002). Today, some countries are still undertaking this process, whereas the USA and the EU countries that had deregulated their airline markets earlier, have since reached more advanced levels in terms of deregulation. Although the EU is a common market that encompasses various national states, it has today been formed into a single deregulated domestic airline market (Borenstein and Rose, 2007; Brueckner and Pels, 2007).

The main objective of airline deregulation is to achieve the conversion of markets into more competitive ones. The Airline Deregulation Act aimed mainly to ensure that the industry had a more competitive structure (GAO, 2006; Sinha, 2001; Wensveen, 2007). Similarly, as the European Commission thought of competition violations in the industry as being contrary to the Treaty of Rome, the EU started with deregulation activities (Hassu, 2004). Thanks to competition, efficient, effective and well-managed carriers will be encouraged (Wensveen, 2007) and those carriers that cannot achieve this will retreat from the market themselves without the need for state intervention. At the same time, the expectation is that along with the increasing number of airlines and competition, efficiency, creativity and innovation, as well as more fare and service options will be introduced to the market (Wensveen, 2007). On the one hand, the quality of service is improved, but on the other hand, the aim is to ensure that passengers benefit from this service with lower fares. In order to draw out these benefits and establish competition, entry market is deregulated and new airlines are encouraged to enter this market, similar to existing ones that are also urged to enhance their network structures (GAO, 2006).

However, it is no longer easy for airlines to operate in this competitive market. Since deregulation, airlines have started working in a more dynamic and constantly changing environment. Competitive markets make airlines face the concept of 'competitive ability'. Airlines' ability to continue their operations and be successful depend solely on their being competitive. The requirement to be competitive eventually helps airlines develop competitive strategies in these markets.

\subsection{Porter's Competitive Strategies and Airline Transportation After Deregulation}

According to Porter (1980), even though not all companies that compete in a given industry clearly define their competitive strategy, they certainly have one. The competitive strategy 
that is formed through analysis of the industry as a whole, and making forecasts about industrial developments in the future, understanding competitors and its own position, and converting this analysis into a well-planned road map (Porter, 1980, 1985) and in the end is compiled, so that the company's own capabilities that will ensure superiority are brought together with the benefits of environmental opportunities (Torlak, 2008).

In fact, the concept of competitive strategy in the literature emerged with Porter $(1980,1985)$. Porter placed 'competition' as a focus of the strategy idea instead of planning and 'competitive strategy' as a focus of strategy instead of strategic planning. This approach caused a definite shift in the idea of strategic management, in the sense that the focus shifted from "strategic planning to competitive strategy" (Barca, 2005). Porter takes the competition concept as enhanced competition: direct competition (competition coming from existing competitors), indirect competition (competition coming from substitutes) and potential competition (competition pressure created by new investors that may potentially enter the industry) (Barca, 2005; Sarvan et al., 2003). Taking this as the basis, Porter defines competitive strategy as a concept that is shaped according to the strategic position a firm has in the industry (Kılınç et al, 2009).

According to Porter (1985), there are three general types of competitive strategies that a firm may implement within an industry: Cost Leadership, Differentiation and Focus. These three generic strategies define the general features of competition that will enable a firm to outperform its rivals in the market place (Sarvan et al., 2003).

Cost leadership strategy is a strategy based on a firm's focusing on cost, so that all the activities are designed to reduce cost and thus the firm is able to compete with competitors by offering lower prices to customers with low cost advantage. In cost leadership strategy, firms aim to offer simple products to typical customers (Miller and Dess, 1996). Designing products or service appropriately, so that the manufacturing process or the presentation is made easier, and having a large volume by serving big customer groups, will ensure that the firm achieves a cost advantage.

In differentiation strategy, a firm uses certain features that are regarded as important and valuable by the customer and it differentiates the product or the service it offers, striving for uniqueness in its market. The firm is rewarded with high prices for this uniqueness (Porter, 1985). Differentiation strategy is not only composed of the differentiation the business will make in products and services, but it is also a competitive strategy to bring differentiation in all the activities of the firm that create a value, so that the firm generates yield above the average (Ülgen and Mirze, 2007). However, this differentiation strategy does not suggest that the firm shall ignore the cost items (Porter, 1980).

Focus strategy is about focusing on a specific customer group, production and distribution line or on a specific geographical market, and shaping all operational activities according to the target selected (Aktan and Vural, 2004; Dinçer, 2007; Hunger and Wheelen, 2007). Cost leadership and differentiation strategies target the market in general, whereas a focus strategy aims at a narrow area within the industry. It aims to form a strategy for this narrow market scope and provide services in this area in a more successful way than its competitors (Porter, 
1985). Thus it excludes other areas and specializes in one single area, earning the capability to offer services in a more efficient and productive way, eventually, as with the other two strategies, will gain a competitive advantage. Focus strategy may be implemented in two ways; by 'focusing on cost leadership' or by 'focusing on differentiation'.

According to Porter (1980), these three strategies are alternatives to one another and that a firm with the lowest cost and a firm that fully implements differentiation are two different qualities that are hardly compatible because successful implementation of each strategy requires different competencies, resources, organizational arrangements and management styles. So, it does not seem possible that a firm is eligible for each of these three strategies at the same time (Porter, 2008). Firms that do not clearly implement any one of these three strategies are seen as stuck in the middle and there is a high probability that they are faced with failure.

With the impact of increasing competition after deregulation, airlines have started to develop new competitive strategies. Deregulated markets force airline operators to develop new strategies in order to protect themselves from competition and they also open up the path for the implementation of these new strategies. In other words, airlines that were unable to take managerial decisions or to implement them freely prior to deregulation have now become able to shape their strategies by way of using certain competitive tools thanks to the flexibility they have earned through deregulation. Numerous studies conducted on strategies that were developed as a reaction of airline operators to deregulation in these markets (Chang and Hsu, 2005; Chang and Williams, 2002; Douglas and Cunningham, 1992; Gillen and Gados, 2008; Gillen and Morrison, 2005; Goll et al., 2006; Jiang, 2007; Kangis and O'Reilly, 2003; Kling and Smith, 1995; Knorr and Zigova, 2004) show that these new strategies may be defined in relation to Porter's generic competitive strategy classification. The observation is that airlines within the deregulated markets have started to position themselves in a clearer way in relation to Porter's differentiation, cost leadership and focus strategies as well as implementing these strategies in a clearer fashion (Douglas and Cunningham, 1992; Gillen and Gados, 2008; Goll et al., 2006; Graf, 2005; Hunter, 2006; Jiang, 2007; Kangis and O’Reilly, 2003; Kılınç et al., 2009; Kling and Smith, 1995).

One of the most significant outcomes of deregulation is that new entrant airlines developed a 'low cost carrier' model based on cost leadership strategy. Freedom of pricing resulting from deregulation is the most significant and fundamental factor playing a role in the emergence of this strategy. The fact that airlines are able to keep their costs to a minimum and determine low fares as they wish, enables them to implement this strategy. Emergence of low cost carriers in the US by the end of the 1970's, in Europe by the end of the 1980's (Gillen and Gados, 2008; Graham and Shaw, 2008; Graham and Vowles, 2006; Jiang, 2007) and in Turkey in 2005 after having deregulated its domestic market in 2003 is an indicator of the fact that deregulation is an effective factor.

Incumbents, having been challenged by the new airline operators that entered the market using a cost leadership strategy and intensifying competition, were also obliged to develop an appropriate competitive strategy themselves. Prior to deregulation, traditional airline 
operators used to work with a model close to the differentiation strategy and, after having entered into competition with low cost airline operators, they have started implementing the differentiation strategy even more clearly. Competition is a leading factor that has had an impact on the development of this strategy, but the fact that deregulation lifted the barriers that prevented the implementation of a differentiation strategy, also played a role. Differentiated airlines developed a new network system called Hub and Spoke (H\&S) and started seeing computerized reservation systems (CRS), frequent flyer programs (FFP), technology and innovation as strategic tools. Now it is on their agenda to use these components as strategic parts of their differentiated products.

Airlines, in order to compete in deregulated markets, have developed new competitive tools that were previously either not in existence or even if they existed, were not seen as strategic tools. They try to gain a competitive advantage by planning prices, frequency, departure times, on-board services, network structure, innovative activities, mergers and acquisitions, alliances, human resources and use of technology in line with the requests and needs of passengers. These tools at the same time are components that airlines use to create customer value and they have become competitive tools that they may be used in a more flexible way after deregulation. Airlines know that in deregulated markets, as a result of competition, it is imperative to provide differentiated services and that these components are to be blended in accordance with the expectations of different customers in different markets or of different customers in the same market. These components provide a certain cost advantage as well as efficiency and productivity to the airlines, so that they may be more at the forefront in competition.

\section{Competitive Tools of Airlines in Deregulated Markets}

According to the literature and the practical examples analyzed, airline operators have mainly ten effective competitive tools to shape the competitive strategies that they develop in deregulated markets (price, frequency and departure time, network structure, mergers \& acquisitions and alliances, travel agency commissions, frequent flyer programs, computerized reservation systems, human resources, innovation and technology, and service quality). Use of these above mentioned tools as a competitive advantage varies according to the competitive strategy each airline operator implements and different competitive tools emerge in each different strategy. However, after all, all of these function as an important strategy component enabling airline operators to create a competitive advantage.

Price: As a result of deregulation, in today's world, for an airline that has been liberalized in pricing decisions, price has now become one of the most important tools for survival and is even superior to others (Kangis and O'Reilly, 1998). Additionally, price is a significant demand determinant in airline transportation (Doganis, 2002; Hanlon, 2007).

Price differentiation that is made by taking demand-based pricing method as the basis and considering the prices of competitors are important elements of competitiveness in deregulated airline markets. Thanks to price differentiation, an airline may maximize its yield with different prices in different market segments for the same service it offers. It may be said that price differentiation implemented with Yield Management Systems is a pricing strategy 
developed by traditional airline operators as a reaction to deregulation and against new operators making entry (Knorr and Zigova, 2004; Malighetti et al., 2009).

After deregulation in the USA and in the EU, the first strategy developed was the implementation of low prices and the undertaking of large volume activities. This strategy was especially implemented by airlines that had recently entered the market and which had adopted cost leadership strategies (Kangis and O'Reilly, 1998). In addition to this, high prices are an integral part of prestigious high quality service delivery addressing specific customer groups.

Flight Frequency and Departure Time: The frequency of flights and any slight changes to departure times would create a major impact on the purchasing behavior of passengers. When an airline starts taking advantage of flight frequency on a given route, the competitive value that this advantage brings is multiplied (Wensveen, 2007). This is because in airline transportation, the benefits of being at the desired location at the desired time are multiplied by frequent flights.

Frequency brings yet another competitive advantage with computerized reservation systems (CRS). Airlines that have more flights will have more visibility on CRS screens as well and that will give them a greater advantage compared to competitors in ticket reservations and sales (Holloway, 2002). Additionally, high frequency to be offered by airlines which are in an alliance group would be a factor in weakening the position of a competing third airline. This opportunity would increase the flexibility of time-sensitive passengers and thus would make the cooperating parties' services even more attractive (Stragier, 2001).

Studies shows that departure and arrival times of a flight are other certain important factors that affect passengers' preference regarding airlines. Departure time is a leading factor that affects the airline preference of passengers that fly particularly short-distance and for business purposes (Doganis, 2002).

Network structure: In today's deregulated markets, the network structures of airlines have become one of the most important factors that affect their competitiveness as transportation is offered as a service over a network. Network structures are shaped according to their strategies and airports selected as operational hubs have an impact on the costs and yield of airlines.

During the regulatory period, since there was no flexibility concerning market entry, airline were not able to shape their network structures as they desired and so most of the time they had to operate in a line network or grid network structure from one point to another. However, deregulation created a new environment which made airlines re-think their marketing strategies and re-form their network structures accordingly. Within this context, transition to H\&S network structure is one of the most significant changes created by deregulation (Brenner et al., 1985; Burghouwt et al., 2002). Basically, the H\&S network structure suggests a system whereby passengers are brought from spoke airports to a central hub airport, collected there and distributed again from this hub airport to spoke airports. The H\&S network structure creates a much greater network and thus increases demand and decreases 
unit costs.

Prior to deregulation, established airlines used to have flights from one point to another but, thanks to the H\&S network structure system, they have started protecting their own routes against low cost airlines that entered the market following deregulation. This structure was first developed by Delta Airlines and has since been taken as an example by many other traditional airlines (Sheth et al., 2007).

Another feature of H\&S network system is that it may be used as a barrier against market entry. An airline that operates using this network structure generally gains strength in the market at the hub airport thanks to the advantages brought by the system. It is rather difficult for another airline to enter into the hub airport and from this airport to the other spoke airports in the system.

Other airlines try to compete by flying from one point to another with their line network strategy. A line network structure is not deployed around a hub airport but rather connects cities on a linear route (Hanlon, 2007). This structure is a network strategy that supports a cost leadership strategy. A low cost carrier that has no stopovers but only direct flights does not have to wait for passengers arriving from connecting flights and thus will reduce the turnaround time; in the end, with the impact of short-distance flights, it will increase the frequency of its aircraft utilization (Şengür, 2004).

Some regional airlines that take advantage of deregulated markets and follow a focus strategy establishing their networks around one or two hub airports because they have a role of feeding the hub airports of major carriers (Burghouwt et al., 2002). If a regional airline co-operates as such with a major airline that follows a differentiation strategy it will gain a remarkable competitive advantage over its rivals.

Mergers, Acquisitions and Alliances: One strategic response airlines give to the impact of deregulation is moving into new structuring in the form of mergers, acquisitions or alliances. A fast consolidation has been encountered in many airline markets after deregulation.

Three different synergies can be identified created with airlines' merger and acquisition strategies. Thanks to the operational synergy created, cost effectiveness is achieved in various areas, such as supply, sales, maintenance, scale benefits at airport activities, sharing of overheads and information technologies. With network synergy, undesired routes are excluded, costs are reduced, destinations that create a value are included in the network so that demand is increased and resource utilization is more efficient. Thirdly, growth ensures an eligible basis for higher bargaining power and effective capital management, so that airlines reinforce their competitive positions (Cento, 2009).

Acquisitions in the airline industry have mostly been acquisitions of regional airlines by major airline operators. In particular, the major airlines that use the H\&S network structure acquire regional airlines that feed in traffic to their own hub airports, aiming to become more effective and dominant in this market. This strategy is frequently seen in the US domestic airline market since deregulation. 
Mergers and acquisitions in the EU are seen among airlines that follow a differentiation strategy. Airlines that follow a cost leadership strategy on the other hand, may sometimes go for a mergers or acquisitions strategy as well. This strategy is re-shaping the scale of national airlines and the competition among carriers (Cento, 2009).

Alliances in airlines, which is yet another strategic practice, requires coordination among carriers on topics such as fares, flight schedules, seat capacity, and marketing activities, so this is actually a model close to mergers (Polley, 1999; Stragier, 2001). Thanks to strategic alliances, network structures complement one another; the operator has a larger and wider market and thus has more market dominance (Gerede, 2002).

What mergers, acquisitions and alliances give as the greatest advantage is entry new markets. By these strategies, airlines will be able to enter the markets that are not easy to enter, gain slots, and have access to airport slots and gate positions which are valuable resources at airports that have capacity issues and merge their flight networks (Gerede, 2002). Thus, the market grows and expands and airlines become more effective in their marketing strategies. This is why these above-mentioned strategies are presented as significant competitive strategies in the airline transportation market.

Travel Agencies' Commission: As a result of the freedom in marketing brought to airline transportation by deregulation, travel agencies have become the main tool airlines use to sell their services. Thus, the increasing competition between airlines gave travel agencies the power to seek more commission than they could have asked during the regulatory period (Brenner et al., 1985). In addition to the commission airline operators pay to travel agencies, they also make special deals with them to give bonus commissions. As a result, major airlines gain more competitive advantage over smaller airlines because travel agencies that are willing to earn more commission convince their customers to purchase tickets from the major airlines with which they make bonus commission deals.

Frequent Flyer Programs (FFP): When frequent flyer programs were first used by American Airlines in 1980, they were regarded as an artificial tool added to attract more attention to advertisements (Levine, 1987). However, they are nowadays seen as key for airlines to remain competitive in this market The main reason for this is that in the competitive environment following deregulation, it was difficult for airlines to retain customers. FFP encourage passengers to travel with a single carrier for each trip with the miles that it rewards passengers. All airlines that follow a differentiation strategy have FFP (Cento, 2009).

Computerized Reservation Systems: CRS developed in the 1960's and the 1970's were simple devices that promised greater time and labor efficiency by processing large amounts of flight reservation information during a time of strict control on market entry and prices. However, after deregulation, CRS was converted into a significant competitive tool. Complex pricing systems, flight schedules and ticketing methods demanded CRS in deregulated markets. Along with deregulation, many airlines extended their airline reservation and ticketing systems to travel agency offices in order to increase the service delivery capabilities of the agencies (Brenner et al., 1985). Thanks to the CRS, airlines now have better access to more customers. 
Human Resources: Knowledge and creativity of managerial level human resources play an important role in forming the main strategies that will make airlines successful in the long run, whereas it is operational level human resources that make functional strategies a success and this will facilitate the realization of the main strategy. The quality of human resources is the most important factor for an airline in the sense that it differentiates the firm from its competitors in deregulated markets and it is this factor that will make the airline successful (Barney and Wright, 1997; Guest, 1987; Poole, 1990; Yüksel, 2007).

Innovation and Technology: Cost pressure created by competition following deregulation obliges airlines to be efficient. It is inevitable, especially for airlines, that they follow a cost leadership strategy to function efficiently and this is achieved through process innovation that enables development of efficient business processes. The firm may radically change the way of doing practices via this process innovation and achieve competitive superiority and differentiation (Kırım, 2006).

Airlines use information technologies on an operational level for activities such as schedule and crew planning, check-in, seat allocation, flight plans and weather forecast reporting, load and balance calculations, ticketing, inventory and reservation management, maintenance management, and baggage processing and tracking. They also use information technologies on a strategic level for activities such as market and competitive structure analysis within the industry, demand forecast, new product development, strategic pricing and yield management, retention and development of business models by communicating with other airlines they are in cooperation with (Buhalis, 2004). Thus, information technologies not only create a competitive advantage by themselves but they also function as a trigger for values that promise competitive superiority, such as innovation and strategic positioning (Şengür and Kuyucak, 2009).

On the other hand, in recent years, Internet technology has been offering numerous opportunities to airlines to be innovative. The Internet is more like a distribution channel for airlines and it enables reservations and ticket sales to be undertaken with less cost and to a wider customer group.

Service Quality: Service quality is a measure that shows to what extent customer expectations are met by the service delivered. Service delivery of good quality requires that customer expectations are met and even exceeded in today's competitive environment (Öztürk, 2009). Therefore, service quality is a concept associated with customer expectations. Following deregulation, customers' perception of airline transportation and their expectations of airlines started to change because the increase in service diversity is yet another outcome of deregulation; as market entry is deregulated, the number of carriers has increased and this has led to variety in airline service delivery. As passengers now have more options when compared with the pre-deregulation period, airlines are obliged to offer services that are superior and of better quality in order to be preferred by passengers. Service quality of an airline is ensured by good planning of product features according to the targeted passenger group, so product features in deregulated markets are extremely important from an airline's competitiveness perspective. Components that form airline service delivery and impact 
service quality, such as price, scheduled based features, comfort based features, and access to service delivery and image (Doganis, 2002) were not under the control of the airline before deregulation. However, these may now be used as competitive advantages in deregulated markets.

\section{Methodology}

In this research, qualitative research methods and techniques that enable the undertaking of in-depth and multi-dimensional analysis on current developments in any environment and explain why and how decisions related to social events and cases are made were employed (Yıldırım and Şimşek, 2008). In this qualitative work, the aim is to present a descriptive and realistic picture related to the topic. All the qualitative data collected has been analyzed using a descriptive analysis method.

Research data was collected between 07.07.2010 and 07.09.2010 via a semi-structured interview method. With this in mind, an interview form relating to the literature was prepared and interviews were carried out with senior managers of airline companies in the research population. Both during the preparation of the interview forms and during the analysis of the data, Porter's (1980, 1985) 'Five Forces Model' and "Generic Competitive Strategies" formed the basis of this work.

The population of this study is composed of Turkish airline companies that were authorized to operate scheduled flights in domestic market as of June 2010 by the General Directorate of Civil Aviation (shgm.gov.tr). These carriers are Turkish Airlines, Onur Air, Atlasjet, Pegasus Airlines, SunExpress, Borajet and AnadoluJet. Of these, AnadoluJet is not necessarily a separate operator, but a sub-brand of Turkish Airlines operating in the domestic airline market. However, AnadoluJet is regarded as the most significant strategic response of Turkish Airlines to deregulation in the market and it is seen to have had a major impact on the market as a whole through its operations, so we saw fit to look at this area in this study.

Respondents in interviews were selected using a purposive sampling method to increase the transferability. It was arranged so that interviewees would be those involved in the strategic decision-making processes and were authorized, senior level managers fully knowledgeable regarding the research topic. These were ten senior level managers and one specialist working at the general directorate, commercial directorate, regional flights directorate, domestic flights directorate, revenue and route management directorate, sales and marketing directorate, regional directorate and, strategic planning and investment department.

In order to ensure a consistency of interview method used as a data collection tool in this qualitative research, all interviews were carried out identically. For this reason, all interviews were undertaken by the same researcher, in the same manner.

The researcher undertaking the interviews attempted to keep the interviews as long as possible, so that the responses given better reflected the reality. The interviews took two hours on average. In order to further enhance the internal validity of the research, by the end of the interview, issues where interviewees hesitated were posed as a question again in order for the interviewer to try to confirm whether the answers were accurately understood or not. 
Additionally, after having analyzed and interpreted the data collected, reports were generated, then submitted to the managers who provided the data so that the managers could provide feedback on the reports to discover if there were any misunderstandings or misinterpretations by the researcher. Only two feedbacks were received and there were no negative comments or corrections.

\section{Findings and Discussion}

\subsection{Competitive Structure in Turkish Domestic Airline Market after Deregulation in 2003}

Price determination in the Turkish domestic airline market was deregulated in 2001 by way of an amendment made in Law (numbered 2920) on Turkish Civil Aviation (Official Gazette, 2001). However, it is not possible to claim that this amendment alone brought about deregulation. The actual deregulation came into force in 2003, when the barriers to market entry were removed; this provided the primary condition for competition. After 2003, the domestic market broke away from the monopolistic structure and was converted into a market where multiple numbers of airlines operate. In Table-1, airlines that entered the domestic market up until December 2011 following deregulation are shown, where prior to 2003, it was only Turkish Airlines operating; dates they entered the market and their current status can also be seen in the Table.

Table 1. The Date Airlines Started Domestic Flights1

\begin{tabular}{|l|l|l|}
\hline Airline & The date it started domestic flights & Notes \\
\hline Fly Air & October 20., 2003 & Transportation license annulled \\
\hline Onur Air & December 9., 2003 & Continues to this date \\
\hline Atlasjet & July 1., 2004 & Continues to this date \\
\hline Pegasus Airlines & November 1., 2005 & Continues to this date \\
\hline SunExpress & March 26., 2006 & Continues to this date \\
\hline AnadoluJet & April 23., 2008 & Continues to this date \\
\hline Borajet & May 7., 2010 & Continues to this date \\
\hline Turkuvaz Airlines & September 22., 2010 & Transportation license annulled \\
\hline Sky Airlines & January 15., 2011 & Resigned from domestic market \\
\hline
\end{tabular}

Source: General Directorate of Civil Aviation (www.shgm.gov.tr)

Findings show that competition among airlines in the domestic market is shaped according to the network structures formed by the carriers. Although all scheduled airlines in the market compete with one another in the general sense, airlines that select Atatürk International

\footnotetext{
${ }^{1}$ Fly Air seen on the Table resigned from the market after having operated for a certain period of time, so it is no longer operational in the market. Additionally, Sky and Turkuvaz Airlines that entered the domestic market after the collection of data for this research resigned afterwards. For this reason, they have not been included in the scope of research.

2 AnadoluJet is not a separate operator but an airline established as Turkish Airlines' sub-brand.
} 
Airport in Istanbul as their hub for flight operations and airlines that select Sabiha Gökçen International Airport in Istanbul as their hub, actually enter into direct competition among themselves. As a result, Turkish Airlines, Atlasjet and Onur Air in one group, and Pegasus Airlines, AnadoluJet and SunExpress in another group are firms that directly regard one another as competitors.

When we consider that each airport pair should be regarded as a separate airline market, this finding is quite logical. The product offered in airline transportation is a transportation service between two points. If any one of these points change, a totally different product would emerge. Additionally, when we consider the fact that nearly a quarter of the population in Turkey is located in Istanbul and its environs, and that there is a long distance between Atatürk International and Sabiha Gökçen International Airports, even if the starting point is Istanbul, it is natural that these two airports create different markets.

Tools that airlines use in order to compete with competitors and points of superiority may vary. However, findings show that competitive tools that emerge in the domestic market are service quality, extensive network structure and price.

New markets opened up in the domestic market as private airlines entered the market after deregulation. However, vitality has been encountered mainly between Istanbul and major cities of Turkey such as Antalya, Adana, Trabzon and Izmir which are densely populated, developed cities with their economic, commercial and tourism activities. In these above mentioned markets, there is more than one airline undertaking operations. This is why there is more competition in these markets where the operations of airline operators coincide.

When we consider the balance between airlines in the market from the size and power perspective, we see that Turkish Airlines has a different position. Due to the fact that Turkish Airlines has been in the airline transportation business for a longer period of time compared to other airlines, it has immense experience and know-how and the advantage of being a national airlines company. All of these factors give bring Turkish Airlines a competitive advantage. For this reason, it is advisable to position Turkish Airlines separately from other private airlines in the competition structure of this market.

Although legally all barriers to market entry have been removed along with deregulation, we still see some barriers to entry in practical terms. The most significant barrier to market entry is a lack of sufficient capacity at Atatürk Airport. In addition to the vitality brought by deregulation, Turkish Airlines grew quite fast and eventually Atatürk Airport reached a point where it may no longer respond to this fast growth. This lack of capacity is reflected to airlines in the form of slot problems. More importantly, due to the lack of sufficient capacity in recent years, the civil aviation authority no longer permits new carriers from entering the market with Atatürk Airport as their hub. In addition to this, during the initial years of deregulation in the domestic market, airlines used to exhibit infrastructure deficiencies at airports, with some airlines switching from charter flights to scheduled flights lacking experience, so there was a requirement for them to make new investment. The field of human resources also encountered issues due to the fact that they could not catch up with this fast growth in such a short period of time and all of these factors are regarded as barriers to 
market entry during the post-deregulation period.

As there is more than one airline in domestic routes operating, it suggests that there are now more options for passengers in many city pair markets. For passengers, it is now possible to prefer one firm ahead of another based on the quality of service offered or the ticket price. Thus, passengers have a stronger position against airline companies when compared with the pre-deregulation period. Prior to deregulation, it used to be only passengers with high income levels that could afford to use air transportation mode in domestic market, whereas now middle income level groups can afford to do so. It may be talk about a new group of customers that are price-sensitive has occurred in the domestic airline market in recent years. Customers that create a value for the airlines are assessed, market segmentation is made and tailor-made marketing strategies are developed for these value creating customers.

When the developments in transportation modes and options in Turkey are considered, land transportation is still the most preferred transportation mode of passengers, so it may be said that land transportation has probably the highest potential to compete with airline transportation; but it cannot be claimed that as speed and journey duration factors are taken into consideration, land transportation can compete with airline transportation. High-speed train transportation is not yet widespread, so it is unlikely to create competition as a substitute product. However, the Ankara - Eskişehir high - speed train reaching all the way to Istanbul is seen as a threat by airlines.

\subsection{Responses of Turkish Airline Companies to Deregulation of 2003}

\subsubsection{Onur Air}

Onur Air was a charter airline before 2003 when it became one of the first carriers to introduce domestic scheduled airline transportation as deregulation gave the right to enter this market. Until 2003, there was only one airline company operating in the domestic market and, as the prices were most of the time high, it was only high income level customers that were targeted; however Onur Air, with its entry the market, targeted middle income level customers. In order to fulfill this strategic objective, Onur developed a strategy of offering low fares with low cost and a low profit margin and addressing the needs of an extended group of customers in the domestic market with low fares. This strategy became feasible as domestic market was deregulated and restrictions on market entry and prices were abolished. When compared with Turkish Airlines, Onur Air has a more advantageous cost basis and with Turkey having a wide geographical structure, these factors are regarded as important aspects that form the basis for the execution of this strategy. Onur Air uses this cost advantage that forms the essence of its strategy in order to offer lower prices by reflecting them onto fares and thereby attracting more passengers, instead of gaining higher yield.

The most effective factor that reduces cost is the annulment of extra services offered by traditional airlines and focusing only on the safe transportation of passengers from one point to another; thus the Onur Air customer profile has passengers that are willing to reach their destination at affordable prices rather than insisting on comforts. After having realized that though offering lower prices works, offering a single fare is insufficient in competition, Onur 
Air started implementing yield management and transited to a dynamic pricing system. Yield management is not necessarily based on software programs that require high levels of investment cost, but is rather executed by manually tracking competing airlines' prices. Within this context, most of the time Turkish Airlines fares are tracked as the company is seen as the price-maker in the market and Onur tries to compete with prices that are lower than those of Turkish Airlines.

Onur Air's network strategy aims to reach high load factor by having an extensive network structure. Within this context, Onur, with its line network structure model centered at Atatürk Airport, operates direct flights to Turkish cities popular with passengers. Onur Air started increasing the number of city pairs at first and then headed towards increasing flight frequency in these markets. It mostly targets passengers that prefer land transportation, so as much as possible, it operates in such city pair markets where travelling by bus takes longer than eight hours; because otherwise, intercity bus transportation will be a significant threat from a competitive perspective.

When the strategy of Onur Air is analyzed, it can be said that it aims to implement cost leadership strategy from Porter's competitive strategies. Low prices that are offered by basically an extensive network structure, and a reduction in cost with operational processes as much as possible are regarded as the most remarkable strategic tools the operator uses against competitors in order to gain a competitive advantage. It aims to reduce unit cost by operating flights with larger aircraft that have greater seating capacity and on routes that have higher passenger potential as well as by discontinuing extra services that may be regarded as luxurious. Though Onur Air exhibits signs of a low cost airline by keeping seat pitch to a minimum, selling food and beverages onboard and executing yield management, it also has some attributes that would contradict this strategy. The most important one is that it operates from Atatürk Airport where air traffic is the busiest rather than a secondary airport. The second attribute is that its fleet does not have a standardized structure, but rather it has various types of aircraft in its fleet; however, it plans to form a single type fleet structure in the future. Its third attribute is that most tickets are sold through travel agencies. All these attributes would cause an increase in the cost of Onur Air and would contradict the general practices within a cost leadership strategy in airline transportation.

\subsubsection{Atlasjet}

Atlasjet used to operate charter flights within its tour operating system, but later started its activities in scheduled domestic transportation following deregulation; Atlasjet made all the changes required by the scheduled airline transportation business after having started operating in domestic routes and formed its organizational structure accordingly.

Atlasjet was the first private airline in Turkey to become a member of the International Air Transport Association - IATA. It benefited from this advantage and focused on 'interline' transportation in the domestic market. For this purpose, Atlasjet signed interline traffic agreements with many other airlines members of IATA, became member of global distribution systems and migrated to electronic ticketing. Thanks to these agreements and to the technological infrastructure investments it has made, Atlasjet undertakes domestic 
transportation of international passengers that come to Istanbul. This strategy which developed after deregulation is regarded as a conscious action taken to ensure a competitive advantage against the other airline companies.

Atlasjet always preferred to be an operator that emphasizes service quality since from its entry into the domestic market, and in order to keep its service quality at a high level, it has undertaken significant investments in technology. Technologies such as electronic ticketing, membership of CRS's, Direct Control System, Self-Check-In, giving passengers PNR numbers with Short Message Services, specific loyalty programs for all customer groups, and i-phone ticket sales application used in service delivery, so that passengers' access to services is facilitated and a comfortable flight is promised. In addition to this, services that create a perception of high level service quality, such as food and beverages being free of charge on board, passengers being transferred to their final destination by shuttle buses again free of charge, are offered. Customer requests, needs and complaints are also systematically and continuously measured in order to evaluate and improve service quality.

Atlasjet's price strategy is not about offering low prices to passengers such as low cost carriers, but rather to sell its service at relatively high prices in return for the service quality it offers. However, it can be seen that Atlasjet's high prices are still more affordable than those of Turkish Airlines which follows the same strategy. For this reason, passengers travelling generally with Turkish Airlines for business purposes prefer to fly with Atlasjet when they travel for personal reasons because passengers' sensitivity to price increases on such trips. Atlasjet executes yield management within the context of price strategy, but against this yield management, Atlasjet does not exhibit a great discrepancy between its lowest and highest prices in a given market. Instead, it is able to make a more balanced pricing when compared to other airlines that also operate yield management.

With this strategy, Atlasjet is targeting customers that do not have high price sensitivity, but attach importance to quality. Basically, Atlasjet carries passengers from its own tour operator. Since it serves various customer groups that travel for tourist purposes, business purposes and VFR (Visiting Friends and Relatives), Atlasjet has two different classes, business and economy, for the Istanbul-Bodrum route. Atlasjet is actually the only airline among all private companies that has two different classes on board. For its business class passengers, Atlasjet offers special services, such as airport lounge services that make them feel privileged, provides inner-city transportation with shuttle buses and allocates these passengers dedicated check-in desks. As it provides services to business class passengers, great importance is attached to on-time performance. On-time performance is one of the most important airline service delivery components for these passengers. Atlasjet sees this as an important competitive tool used to attract and retain business class passengers.

With these practices, Atlasjet aims to create the perception of an airline that is of high quality and different in the eyes of passengers, and by using its service quality, it aims to compete with other airlines in the domestic market. In this context, it can be said that since deregulation, Atlasjet has entered the market with a differentiation strategy of its own.

As Atlasjet has entered the market for the first time with a differentiation strategy, it followed 
an extensive network structure and growth strategy in the domestic airline market like Onur Air. For this purpose, it entered many new markets where there previously had been no operations as domestic airlines and added regional jets to its fleet that are more capable of operating effectively at airports in the eastern part of Turkey. However, it could not ensure sustainability of its operations in these markets. The reason for its resigning from these mentioned markets is regarded as being a lack of an effective differentiation strategy implementation because the economies of the routes Atlasjet was trying to operate in were not ready to afford the high prices offered within the framework of a differentiation strategy. Thus, Atlasjet moved from operating an extensive geography and instead decided to be more focused. Markets it started concentrating on afterwards are rather tourist markets and their economies are relatively higher when compared with other domestic airline markets. Currently, Atlasjet seems to be an airline focusing on flight destinations to which it can carry passengers from its own tour operator. In conclusion, it may be said that Atlasjet developed a differentiation strategy as a response to deregulation as it entered the market. However, after this it started concentrating on a specific geographical market and started implementing a focused differentiation strategy.

\subsubsection{Pegasus Airlines}

As Pegasus Airlines operated in charter transportation, it was acquired by ESAS Holding in 2005, and then built itself a new mission, 'being a low cost airline company operating scheduled flights in domestic and international routes'. Thus, it started operating scheduled flights in the domestic airline market the very same year. It realized that the most effective and easy way to move from charter transportation to scheduled transportation was primarily through having a presence in the domestic market. The necessary ground was set as the barriers facing private airlines were eliminated in the domestic market. Airlines were supported by government incentives and the economic conditions at the time were suitable for operation in the Turkish market.

Pegasus Airlines entered the domestic market with its cost leadership strategy. Prior to entry the market, some European low cost airlines such as, Ryanair and Easyjet, were analyzed and the operators were re-structured in accordance with a cost leadership strategy in line with conditions in Turkey.

The most important component of Pegasus Airlines' cost leadership strategy is the low price strategy. As it reduces cost and reflects that onto its prices by operational efficiency and productivity, it offers low prices. The main factors that ensure the airline's operational efficiency and productivity are the selection of a secondary airport as the hub, the formation of a standardized fleet structure, intensive use of technology, ticket sales over the Internet and delivery of plain and simple services.

As a result of a competitive analysis conducted prior to its entry the market, it was decided that Sabiha Gökçen Airport should be the hub of flight operations as a differentiation in competition instead of being the fourth carrier at Atatürk Airport after Turkish Airlines, Atlasjet and Onur Air. Thus, by preferring Sabiha Gökçen Airport, Pegasus gained a competitive advantage as it avoided direct competition with other airlines present in the 
market; additionally, it aimed to reveal a passenger demand from the Asian part of Istanbul as well as from certain nearby cities such as Kocaeli and Sakarya that had never been accessed before. More importantly, as Sabiha Gökçen Airport has less flight traffic than Atatürk Airport, Pegasus has been able to reduce the turnaround time for its aircraft and thus increase daily aircraft utilization. This is an effective tool in increasing aircraft productivity and reducing costs. Additionally, the lower fees required by the airport reduce Pegasus Airlines' airport utilization costs. Thus, Pegasus Airlines has been able to achieve remarkable cost advantages when compared to its competitors.

On the other hand, the assumption is that in the near future, a slot arrangement is to be initiated at Sabiha Gökçen Airport. Besides, as the operation of the terminals of airport as transferred to the private sector within the context of a Build-Operate-Transfer (BOT) Project, there has been an increase in airport fees as well. All of these developments are regarded as signs which show that Pegasus Airlines will encounter challenges in following a cost leadership strategy in the future.

One other important factor that has an impact on the cost advantage of Pegasus Airlines is its standardized fleet structure. Operating only with Boeing type aircraft, Pegasus is able to reduce cost because of the flight network and spare part pool efficiency. Having a single type fleet helps reduce maintenance, training and spare part inventory costs; it also ensures more flexibility in cockpit personnel planning and fleet management and finally, it reduces aircraft purchasing costs.

Pegasus also offers plain and simple services to keep costs to a minimum. There is no business class, and all flights have one single class which is economy class, so the distance between the seats is kept to a minimum and passenger seat capacity is thereby increased. Additionally, it does not have Very Important Person (VIP) or Commercially Important Person (CIP) that would cause additional cost, and food and beverages are sold to passengers on-board. Charging passengers more when they select a seat prior to the flight, offering hotel and car rental services, advertisement spaces on on-board magazines and on the aircraft, as well as the fees charged for any ticket change are all subsidiary income for the airline and they represent an important share of total yield.

Pegasus Airlines has yield management like other airlines in the domestic market. Although it offers very low fares, due to yield management, the fares increase as the flight date draws closer and fares are rather subject to change. As for ticket sales, unlike other airlines, Pegasus has direct sales channels more at the forefront. In particular, in order to increase ticket sales over the Internet, significant technological investment is made so that customers' access to airline services is facilitated. Development of direct sales channels has strategic importance for Pegasus because ticket sales via direct sales channels bring a cost advantage in accordance with Pegasus' strategy. It enables Pegasus to have direct access to customers, so that they may have more of an impact on the customers.

A different strategy seen in Pegasus Airlines is its cooperation strategy with İzAir in domestic routes. Esas Holding, the owner of Pegasus, acquired İzAir, which is regarded as an important brand for the Izmir region. By acquiring this brand, Pegasus aimed to attract the 
passenger potential in that region as well. Flights the airline has from Istanbul are of course open to competition. However, by having flights from a hub like Izmir enables Pegasus to be present in a domain where there is little competition and a high probability of profit.

\subsubsection{SunExpress}

Established in 1989 through the partnership of Turkish Airlines and Lufthansa, in order to operate international charter flights to and from Antalya, SunExpress decided to structure all its flight operations based in Izmir and selected a niche geographical market in domestic market instead of entering markets where there were other carriers present following deregulation. Thus, it enabled the opening up of new markets with the domestic flights it operated from Izmir and started operating in a grid network structure model that is based on connecting cities with one another that had not previously been connected. Eventually, it paved the way for the development of a new flight structure in the domestic market. On the one hand, selecting markets that lack competition and that had never previously been flown brought SunExpress a competitive advantage. However, it proved a challenge for the airline to create passenger potential in these markets.

In addition to its strategy of operating in niche markets, SunExpress entered into high volume markets where passengers are accustomed to using air transportation and attempted to operate there as well, by offering additional capacity. So, one can say that SunExpress is executing both network strategies.

In 2008, SunExpress started operating flights from Sabiha Gökçen Airport as well and thus opened up a third hub for itself after Antalya and Izmir. The reason for selecting Sabiha Gökçen Airport as the hub is assumed to be the fact that Turkish Airlines, that has $50 \%$ ownership of the operator, also wanted to be part of the competition based at Sabiha Gökçen Airport. It is particularly in competition with Pegasus Airlines and thus attempts competitive superiority in the market. Moreover, this is a good example that exhibits the implementation of strategic partnership in order for both Turkish Airlines and SunExpress to be able to compete.

SunExpress is not in direct competition with all the other airlines in the market. It only faces competition in specific city pair markets where other airlines are also present; and the most important competitive tool SunExpress uses is service quality rather than price. However, SunExpress' understanding of service quality differs from that of traditional airlines that provide full services because it is also possible to see the practices of low cost airlines in SunExpress. The aim of SunExpress is only to execute practices that would create value in the eyes of the customer. This is why it adopts the practices of low cost airline that would create value for its services in the eyes of the customer and thus it reduces costs and creates that value.

The strategy of SunExpress may be interpreted as an integrated strategy that blends the practices they believe would create value for the customer from differentiation, cost leadership and focus strategies that are in implementation at many airlines around the world. It also employs the strategy of offering affordable prices that would meet the cost of service 
quality rather than high prices in return for a service of good quality.

\subsubsection{Borajet}

After deregulation, air transportation between major cities, where there is high passenger potential in domestic routes gained momentum. However, although many new markets opened up in this structure, in cities where passenger potential is low or where there is usually STOL (Short Take-off Landing) type airports, air transportation did not develop. This gap was seen as an opportunity by Borajet and so it started scheduled flights in domestic routes with a strategy that may bring these markets to life. All other private airline companies that entered the market before Borajet had first been charter airlines before transiting to become scheduled airlines whereas Borajet was established and started operations back in May 2010 as a domestic airline with scheduled flights.

Borajet entered the market with a regional airline model that basically connects smaller cities to bigger cities in order to capture the momentum it was targeting in domestic routes. Its network and fleet structure were designed according to this strategy as well. With ATR-72 type turboprops in its fleet, it aims to collect passengers from small cities where other airlines do not operate, bring them to major cities and leave the rest of their travel from this hub to other airlines; or another perspective, Borajet is willing to undertake the distribution of passengers to smaller domestic destinations from the hub where they were transported by major airlines. In this context, Borajet is willing to feed airlines that fly between major hubs in the market.

Aircraft in its fleet have a capacity of sixty six seats and are suitable for operating in low potential markets in an efficient and productive way. As the number of seats is limited, it is easily able to reach high load factors in these markets and thus reduce unit costs. Additionally, these markets generally have airports with shorter runways and smaller aprons; it may be extremely difficult and sometimes not even possible for large jets to take off from or land at these airports. Borajet is however, able to undertake effective operations at these airports with the turboprops it has. Another advantage these aircraft have is that fuel and maintenance costs are lower than others. In the long run, it can bring an advantage to Borajet from a labor cost perspective as well. All these attributes that are advantageous for Borajet may be a challenge for other airlines in the sense that airlines in the market operating with their larger jet aircraft may have difficulty in implementing this or even if they implement it, they may encounter other efficiency or productivity problems. So, we can say that with this strategy, Borajet is protecting itself against competition and has seized a competitive advantage. In response to this, since the support services and infrastructure for these aircraft have not been put into place yet in Turkey, Borajet is obliged to construct most of the infrastructure itself. For these reasons, the initial costs of Borajet may be higher than those of other airlines, but still the operational cost in the upcoming term will be lower for Borajet than for many others.

While transporting passengers between two points, Borajet is planning to receive passengers on-board from other intermediary points as well. As Atatürk Airport is the normal destination for most of its flights, Borajet is willing to operate from there; however, as it is not able to get any slots from there, it has flights centered at Sabiha Gökçen Airport. Borajet prefers not to 
enter the routes of its competitors, but rather operates in markets where it can fly for one to two hours with the aircraft in its fleet. It is not able to compete with other carriers in markets where flights take longer than two hours. Additionally, if it enters markets where jet aircraft are operating, its competitive capabilities may diminish. So, Borajet has a regional network strategy in which it flies to short and medium range destinations no other carrier flies to, connecting major and smaller cities through a grid network system.

As we consider all the practices of Borajet, we see that it concentrates its activities in a given geographical area, so it can be seen that Borajet's strategy is the focus strategy from Porter's competitive strategies.

\subsubsection{Turkish Airlines}

Competition that came along with deregulation, forced Turkish Airlines to make changes in its current strategy. Turkish Airlines used to operate on its own in the market and in those times it not only operated flights, but also established an air transportation system, offered services in other areas such as ground handling, maintenance, and training services as well as providing full services to all its customer groups with its network structure on a global scale; so, Turkish Airlines used to follow a differentiation strategy until the deregulation period. However, it was clearly understood that it was no longer possible to compete in the newly-established deregulated market using existing strategies, so it has undertaken certain strategic changes that would inevitably impact the operator. The most significant change has been the modification of the business model and the execution of the elements in certain strategic areas that are required by this new model. Prior to deregulation, Turkish Airlines used to operate the 'yield increase' model whereas in this new context, it migrated to a new strategic target of 'increase of passenger numbers'. In other words, the operator's main aim is to benefit from scale economies by increasing the amount of production and decreasing the unit costs in the domestic market. In order to increase the number of passengers, the aim is to reduce costs and reflect the reduction onto prices, to the benefit of passengers.

After deregulation, the domestic market became rather competitive and costs have become extremely important for all airlines. This is because in this competitive environment, a cost advantage is going to bring a competitive advantage so, for this reason, Turkish Airlines developed cost reduction strategies. However, as cost reduction strategies were put into practice, neither the differentiation strategy, which is the basic competitive strategy of the company, nor service quality were compromised. In other words, cost reduction strategies were implemented not by abolishing services passengers can directly see, but by a series of changes in the processes. Processes have been reviewed in search of efficiency and productivity.

As a part of the efficient fleet planning process, aircraft were purchased when the world economy was suffering crisis, and thus purchasing costs were lowered, daily utilization rates were increased and more productive operations were ensured. Additionally, though the fleet grew, resources excluding the cabin and cockpit crew were kept stable so that there was no significant increase in costs. Eventually, through all these measures, production on a passenger-mileage basis increased, costs were unchanged and productivity was improved. An 
increase in production requires a high volume service purchase from suppliers, so this reinforces Turkish Airlines' bargaining power to reduce its costs.

Another strategic response Turkish Airlines gave to deregulation was the development of outsourcing strategies. It decided to concentrate on its core competences and gave up producing subsidiary services. Within this context, technical services, catering services, ground handling services and call centers have all been converted into stand-alone administrations. These subsidiary functions that were separated from the operator were given a company identity and started their own commercial activities. In the end, they have become more efficient and productive. Thus, Turkish Airlines started supplying such services from these companies for lower rates and achieved a cost advantage instead of doing it internally within its own organization at higher cost. Additionally, these companies provide services to third party enterprises and generate income as well as reducing their unit costs thanks to their economies of scale. Outsourcing strategies not only bring cost advantages but also enable Turkish Airlines to focus on its flight operations and become a more efficient airline and deliver service of superior quality.

In addition to all the changes mentioned above, the most important reaction of Turkish Airlines to deregulation was the establishment of AnadoluJet as a low cost sub-brand, since the AnadoluJet brand has an impact on both the competitiveness of Turkish Airlines in the domestic market and competition in the market in general. Although it has all these cost reduction strategies, it is not easy for Turkish Airlines to compete in the domestic market and ensure productivity with its differentiation strategy because generally carriers entered the market after deregulation with a strategy to lower costs and offering lower prices. This led to a reduction of average prices in the market and the emergence of price competition. Turkish Airlines' strategic changes were insufficient in tackling this competition, so the airline was obliged to establish a sub-airline close to the strategy of other private airlines in the market. With its AnadoluJet brand, that was originally established to provide transportation-focused services only, Turkish Airlines is able to reach a wider group of people that are price-sensitive and, since AnadoluJet is centered in Ankara, it has thus increased the number of hubs in the domestic market. With such structuring, Turkish Airlines will gain market power and challenge market competition.

\subsubsection{AnadoluJet}

AnadoluJet was established as a sub-brand of Turkish Airlines and it may be regarded as the most important reaction of Turkish Airlines to deregulation. In order to operate efficiently and productively in the domestic market where the dynamics underwent a change after deregulation, and to better respond to customer needs, Turkish Airlines established the AnadoluJet brand which operates a different strategy than its own competitive strategy. The basic reasons for establishing AnadoluJet were as follows: to respond to the demands and requirements of the customer profile in the domestic airline market with a more accurate product; to enhance the efficiency of Turkish Airlines' flights from Ankara; and to make it profitable making Ankara a new hub for Turkish Airlines. As Ankara Esenboğa Airport was structured as a hub for the domestic airline market, the aim was to relieve Turkish Airlines 
transit traffic at Atatürk Airport and make improvements concerning this traffic.

Having Ankara as a hub brings many advantages to AnadoluJet. Due to the geographical position of Ankara, following deregulation, AnadoluJet has been able to implement a H\&S network strategy, extremely efficiently in the domestic airline market. Travelling time for domestic flights that start from Ankara, especially in the north-south direction, are currently shorter. Another important impact is that it enables an increase in flight frequency. Frequency is an important tool in AnadoluJet's competitiveness. In addition, customer demands and requirements are analyzed in order to plan flight schedules efficiently. There is always less traffic in Ankara and, using this system, the waiting time for flights that have a connection in Ankara are shortened and thus the airline's flight wave (collection and distribution) costs are reduced. The technical infrastructure of Esenboğa Airport promises facilitated stop-overs in a shorter period of time with fewer problems and eventually at lower cost.

When all these attributes are taken into consideration, we see that Ankara has strategic significance in the structuring of AnadoluJet. AnadoluJet places all these advantages to the forefront and gains a significant competitive advantage.

AnadoluJet's strategy is to abolish many services, reduce costs to a minimum with a simple product and offer low prices to passengers as a result. As a part of this strategy, the distance between seats is kept to a minimum and limited food and beverages are offered to passengers. As a sub-brand of Turkish Airlines, AnadoluJet suffers from the cost disadvantage of Turkish Airlines because of its size, so it cannot be a cost leader in the market. However, it possesses the features of airlines that follow a cost leadership strategy. In response to this, with its H\&S network structure, it differentiates itself from the low cost airlines to a large extent.

Although it is possible to see similar practices at AnadoluJet that one might see at other low cost airlines in the market, when we look from a cost and price perspective, we cannot claim that the airline offers the lowest costs and lowest prices in the market. AnadoluJet formed its strategy by considering customer demands and requirements, as well as determining the niche markets and now aims to respond to the needs of these markets. For this reason, we can say that AnadoluJet's strategy is not exactly one of cost leadership but is closer to a focus strategy. The most important components of its strategy are network structure, flight frequency and price.

\section{Conclusions}

Following deregulation in the Turkish Domestic Market in 2003, there has been a remarkable increase in the number of scheduled airlines in the market and thus increased competition. Eventually, this competitive environment caused airline companies to develop new competitive strategies in order to ensure competitiveness in the long run.

Turkish Airlines as well as other airlines that entered the market after deregulation, tries to stay competitive in the domestic airline market by using a network structure, service quality and price. Each of these three components is strategic tools airlines may shape as they wish, thanks to deregulation. Private airlines that recently entered the market prefer to compete with the price component whereas Turkish Airlines continues competition with its wide 
network structure and service quality component. Findings show that network structures are at the center of competitiveness. The airline that forms a network structure accurately in the market (the hub selected, network model and city pair markets for operations) will obviously gain an important competitive advantage from the beginning.

The first private airlines that entered the market wished to operate with an extensive network structure in the domestic airline market. However, after having thought that this strategy would not bring any success, they decided to implement more focused strategies. Later on, these carriers developed strategies to operate in city pair markets with excess capacity where there is high demand. Airlines that entered the market later, such as SunExpress, Pegasus and Borajet, focused on markets where there were no competitors and they developed more defensive strategies. These strategies are regarded as being important in the sense that they contribute not only to the success of the airline that executes them, but also to the expansion of domestic airline transportation.

We cannot say that there is competition in all the city pair markets in domestic routes. In major developed cities especially there is strong competition, whereas in certain other markets, monopolies are still apparent; Turkish Airlines is the carrier mostly offering services in these monopolistic markets. $49 \%$ of Turkish Airlines is owned by the state and its privatization on the whole is regarded as important to ensure a more efficient and fair competitive environment in the market. After all, privatization is seen as a requirement of deregulated markets.

Although entry the market has been deregulated, there is still a barrier to market entry at Atatürk Airport; the reason being insufficient capacity of the airport that was unable to handle the rapid growth after deregulation. This problem is reflected onto the operations of current airline companies in the form of slot difficulties, but it also makes it impossible to issue market entry permits to new entrant airlines. As slots are unavailable, this has an impact on the strategies of airline companies. There is also the general view that slot allocation among private airlines is not performed efficiently. When we see that the task of slot coordination is under the authority of the General Directorate of State Airports, a public organization, there is the suspicion that it may favor national air carrier. If this function were to be undertaken by an independent entity as is the case in many European countries, it would ensure more efficient slot allocation and greater trust in the market. Additionally, if a certain number of slots is to be allocated to new entries under certain legal regulations, entry the market would be facilitated as well. Human resources problems, infrastructural deficiencies and other operational challenges make the market entry and operating in the market difficult for air carriers; however, these are all challenges that may be overcome.

According to the findings, the most fundamental strategic change encountered by private domestic airlines following deregulation has been their migration from non-scheduled airline operations to scheduled airline operations. This migration means a change of activity areas and the formation of a new mission, so we may conclude by saying that this has altered the corporate level strategies of Turkish private airlines drastically. However, private airlines not only changed their corporate strategies, but also developed new competitive strategies with 
which they have been able to compete within the new framework in the domestic airline market. Thus, they have tried to support their corporate strategies. Borajet is the only exception to this, in the sense that its area of activity, in other words, its corporate strategy was presented as scheduled domestic transportation since the beginning, and this was how it found itself a place in this market with its competitive strategy.

As we consider the competitive strategies implemented by airlines, we can say that, with the basic logic it has, Onur Air aims to execute a cost leadership strategy although it does not embody some of the certain elements mentioned in the literature. Atlasjet is thought to have developed a differentiation strategy focusing on a narrower geography as a response to deregulation. Pegasus Airlines, unlike Onur Air, has developed a strategy closer to the cost leadership strategy mentioned in the literature. SunExpress, on the other hand, is executing a mixed strategy by having blended three strategies, namely the cost leadership, focus and differentiation strategies and adopted relevant practices from them that would create customer value. As for Borajet, it takes regional airline transportation as the model and adopts a focus strategy.

Turkish Airlines, on the other hand, did not compromise its services and continued to follow a differentiation strategy; however within the context of this strategy, it also developed cost reduction strategies. It modified its processes to ensure efficiency and productivity, developed new marketing strategies and established a sub-brand for itself, AnadoluJet, in order to better meet customer needs with a more appropriate product in the domestic market and to operate more efficiently.

It is known that following deregulation in Europe and USA, many traditional airlines followed the strategy of establishing sub-brands and thus adapted to developments. A similar reaction was seen in Turkey with Turkish Airlines. As we consider international examples from different parts of the world, we see that this strategy did not bring fruitful outcomes for traditional airlines because, as Porter suggests, it is never easy to implement two different strategies under a single roof and this strategy has brought nothing but failure to most operators. However, the outcome of this strategy for Turkish Airlines shall be seen in time.

If we are to consider the strategy of AnadoluJet separately, we can say that it has formed itself a network structure that would create strategic superiority in the market. Although it was mentioned during our interview with AnadoluJet that the airline is not in direct competition with private airlines, this strategy is still thought to challenge other airlines in the market because this structuring is enabling AnadoluJet to address a significant portion of the market and capture market power. Moreover, managers of private airline companies believe that AnadoluJet is in competition with them.

As a general evaluation, within the context of Porter's competitive strategies, we can say that all three of Porter's competitive strategies are available in the Turkish market. These strategies have obviously have been developed since deregulation. However, they are not identical to strategies in the literature and this difference is believed to be because of conditions in Turkey. In essence, these strategies are in accordance with Porter's competitive strategies, and they may not be adopted in all their standard forms in all markets, so it would 
be wrong to standardize them for evaluation purposes.

As a result of the research, although there was some monopolistic structuring on some routes, the deregulation of 2003 brought competition to the domestic airline market and forced airline companies to develop different strategies by considering their competitors as well as their customers' demands and requirements.

Restrictions on capacity enhancement at Atatürk Airport have a negative impact on network strategies. It would be advisable to build another airport in Istanbul or change the location of Atatürk Airport in order to eliminate all the capacity restrictions it now has. Apart from this, prices are shaped according to market conditions and airlines act liberally with regard to pricing. Thanks to this liberalization, operators are able to execute their price strategies in a more efficient manner.

\section{References}

Aktan, C. C., \& Vural, İ. Y. (2004). Rekabet Gücü ve Rekabet Stratejileri. Ankara: Turkish Confederation of Employer Associations.

Barca, M. (2005). Stratejik Yönetim Düşüncesinin Evrimi: Bilimsel Bir Disiplinin Oluşum Hikâyesi. Başkent University Journal of Management Research. 5(1). 7-39.

Barney, J. B., \& Wright, P. M. (1997). On Becoming a Strategic Partner: The Role of Human Resources in Gaining Competitive Advantage. Human Resource Management. 37(1). 31-46. http://dx.doi.org/10.1002/(SICI)1099-050X(199821)37:1<31::AID-HRM4>3.0.CO;2-W

Borenstein, S., \& Rose, N. L. (2007). How Airline Markets Work...Or Do They? Regulatory Reform in the Airline Industry. Working Paper 13452. National Bureau of Economic Research. Cambridge.

Brenner, M. A., Leet, J. O., \& Schott, E. (1985). Airline Deregulation. Westport Connecticut: ENO Foundation for Transportation, Inc.

Brueckner, J. K., \& Pels, E. (2007). Institutions, Regulation, and the Evolution of European Air Transport. In D. Lee (Ed.), Advances in Airline Economics: The Economics of Airline Institutions, Operations and Marketing (pp. 1-25). 2. Oxford: Elsevier.

Buhalis, D. (2004). eAirlines: Strategic and Tactical Use of ICTs in the Airline Industry. Information\&Management, 41(7). 805-825. http://dx.doi.org/1016/j.im.2003.08.015

Burghouwt, G., Hakfoort, J., \& Eck, J. R. V. (2002). Airline Network Configurations in the Deregulated European Aviation Market. European Transport Conference Paper. [Online] Available:http://www.etcproceedings.org/paper/airline-network-configurations-in-the-deregul ated-european-aviation-market

Cento, A. (2009). The Airline Industry: Challenges in the 21st Century. Heidelberg: Physica-Verlag HD.

Chang, Y. C., \& Williams, G. (2002). European Major Airlines' Strategic Reactions to the Third Package. Transport Policy, 9(2), 129-142. 
Chang, Y. C., \& Hsu, C. J. (2005). Ally or Merge - Airline Strategies After the Relaxation of Ownership Rules. Proceedings of the Eastern Asia Society for Transportation Studies, 5, 545-556.

Dinçer, Ö. (2007). Stratejik Yönetim ve Işsletme Politikası. (8th ed.). İstanbul: ALFA.

Doganis, R. (1994). The Impact of Liberalization on European Airline Strategies and Operations. Journal of Air Transport Management, 1(1), 15-25. http://dx.doi.org/10.1016/0969-6997(94)90027-2

Doganis, R. (2002). Flying off Course: The Economics of International Airlines. (3rd ed.). London: Routledge.

Doganis, R. (2005). The Airline Business in the Twenty-First Century. Taylor \& Francis e-Library.

Douglas, E. J., \& Cunningham, L. J. (1992). Competitive Strategies in Australia's Airline Deregulation Experience. School of Business Discussion Paper. No: 28. Bond University. [Online] Available: http://epublications.bond.edu.au/discussion_papers/28/

Douglas, G. W., \& Miller, J. C. (1974). Economic Regulation of Domestic Air Transport: Theory and Policy. Washington, D.C.: Brookings Institution.

GAO. (2006). Airline Deregulation: Reregulating the Airline Industry Would Likely Reverse Consumer Benefits and Not Save Airline Pensions. Report to Congressional Committees. Government Accountability Office. United States.

Gerede, E. (2002). Havayolu Taşımacılığında Küreselleşme ve Havayolu İşbirlikleri-THY A.O.'da Bir Uygulama. (Unpublished doctoral dissertation). Anadolu University/Graduate School of Social Sciences, Eskisehir.

Gillen, D., \& Gados, A. (2008). Airlines within Airlines: Assessing the Vulnerabilities of Mixing Business Models. Research in Transportation Economics, 24(1), 25-35. http://dx.doi.org/10.1016/j.retrec.2009.01.002

Gillen, D., \& Morrison, W. G. (2005). Regulation, Competition and Network Evolution in Aviation. Journal of Air Transport Management, 11(3), 161-174. http://dx.doi.org/10.1016/j.jairtraman.2005.03.002

Goll, I., Johnson, N. B., \& Rasheed, A. A. (2006). Strategic Responses to Deregulation and Their Performance Implications in the U.S. Airline Industry. Business and Politics, 8(2), $1-37$.

Graf, L. (2005). Incompatibilities of the Low-Cost and Network Carrier Business Models within the Same Airline Grouping. Journal of Air Transport Management, 11(5), 313-327. http://dx.doi.org/10.1016/j.jairtraman.2005.07.003

Graham, B., \& Shaw, J. (2008). Low Cost Airlines in Europe: Reconciling Liberalization and Sustainability. Geoforum, 39(3), 1439-1451. http://dx.doi.org/10.1016/j.geoforum.2007.12.006 
Graham, B., \& Vowles, T. M. (2006). Carriers within Carriers: A Strategic Response to Low-Cost Airline Competition. Transport Reviews, 26(1), 105-126. http://dx.doi.org/10.1080/01441640500179377

Guest, D. E. (1987). Human Resource Management and Industrial Relations. Journal of Management Studies, 24(5), 503-521. http://dx.doi.org/10.1111/j.1467-6486.1987.tb00460.x

Hanlon, P. (2007). Global Airlines: Competition in a Transnational Industry. (3rd ed.). Amsterdam: Elsevier Butterworth Heinemann.

Hassu, M. (2004). Rekabet Hukuku ve Hava Taşımacılığı Sektörü. (Thesis of Competition Experts). Turkish Competition Authority. Ankara.

Holloway, S. (2002). Airlines: Managing to Make Money. Aldershot: Ashgate.

Hooper, P. (1998). Airline Competition and Deregulation in Developed and Developing Country Contexts - Australia and India. Journal of Transport Geography, 6(2), 105-116. http://dx.doi.org/10.1016/S0966-6923(98)00004-0

Hunger, J. D., \& Wheelen, T. L. (2007). Essentials of Strategic Management. Upper Saddle River: Addison - Wesley.

Hunter, L. (2006). Low Cost Airlines: Business Model and Employment Relations. European Management Journal, 24(5), 315-321. http://dx.doi.org/10.1016/j.emj.2006.08.001

Jiang, H. (2007). Competitive Strategy for Low Cost Airlines. Proceedings of the 13th Asia Pacific Management Conference. Melbourne, Australia. pp. 431-436.

Jordan, W. A. (1979). Airline Regulation in America: Effects and Imperfections. Connecticut: Greenwood.

Kahn, A. E. (1988). Surprises of Airline Deregulation. American Economic Review, 78(2), 316-322.

Kahn, A. E. (1971). The Economics of Regulation: Principles and Institutions. New York: Wiley.

Kangis, P., \& O'Reilly, M. D. (2003). Strategies in a Dynamic Marketplace: A Case Study in the Airline Industry. Journal of Business Research, 56(2), 105-111. http://dx.doi.org/10.1016/S0148-2963(01)00282-X

Kangis, P., \& O’Reilly, M. D. (1998). Strategic Responses to Competitive Pressures: European Air Transport. Strategic Change, 7(3), 167-182. http://dx.doi.org/10.1002/(SICI)1099-1697(199805)7:3<167::AID-JSC361>3.0.CO;2-7

Keeler, T. E. (1972). Airline Regulation and Market Performance. Bell Journal of Economics and Management Science, 3(2), 399-424.

Kılınç, İ., Öncü, M. A., \& Taşgit, Y. E. (2009). A study on the Competition Strategies Implemented in the Airline Companies in Turkey. Selçuk University Journal of Social and Economic Research, 9, 173-185. 
Kırım, A. (2006). Maliyetlerinizi Düşürmek Arzusundaysanız Süreç İnnovasyonunu Öğrenin. Turkishtime Monthly Business and Economy Culture Magazine. May, 116 - 126.

Kling, J. A., \& Smith, K. A. (1995). Identifying Strategic Groups in the U.S. Airline Industry: An Application of the Porter Model. Transportation Journal, 35(2), 26-34.

Knorr, A., \& Zigova, S. (2004). Competitive Advantage Through Innovative Pricing Strategies: The Case of The Airline Industry. [Online] Available: http://www.iwim.uni-bremen.de/publikationen/pdf/b093.pdf

Levine, M. E. (1987). Airline Competition in Deregulated Markets: Theory, Firm Strategy, and Public Policy. Yale Journal on Regulation, 4, 393-494.

Levine, M. E. (1965). Is Regulation Necessary? California Air Transportation and National Regulatory Policy. Yale Law Journal, 74(8), 1416-1447.

Malighetti, P., Paleari, S., \& Redondi, R. (2009). Pricing Strategies of Low-Cost Airlines: The Ryanair Case Study. Journal of Air Transport Management, 15(4), 195-203. http://dx.doi.org/10.1016/j.jairtraman.2008.09.017

Miller, A., \& Dess, G. G. (1996). Strategic Management. (2nd ed.). New York: McGraw-Hill.

Morrison, S., \& Winston, C. (1986). The Economic Effects of Airline Deregulation. Washington, D.C.: Brookings Institution.

Official Gazette. (2001). Law (numbered 2920) on Turkish Civil Aviation, Date: 26/04/2001, No: 24384.

Öztürk, A. (2009). Kalite Yönetimi ve Planlaması. Bursa: Ekin.

Polley, R. (1999). Defense Strategies of National Carriers. Fordham International Law Journal, 23(6), S170-S208.

Poole, M. (1990). Human Resource Management in an International Perspective. International Journal of Human Resource Management, 1(1), 1-15.

Porter, M. E. (2008). Rekabet Stratejisi: Sektör ve Rakip Analizi Teknikleri. (Translated by Gülen Ulubilgen). İstanbul: Sistem.

Porter, M. E. (1985). Competitive Advantage: Creating and Sustaining Superior Performance. New York: Free.

Porter, M. E. (1980). Competitive strategy: Techniques for Analyzing Industries and Competitors. New York: Free.

Republic of Turkey General Directorate of State Airports Authority. [Online] Available: http://www.dhmi.gov.tr

Republic of Turkey Ministry of Transport, Maritime Affairs and Communications Directorate General of Civil Aviation. [Online] Available: http://web.shgm.gov.tr

Sarvan, F., Durmuş Arıcı, E., Özen, J., Özdemir, B., \& Tarcan İçigen, E. (2003). On Stratejik 
Yönetim Okulu: Biçimleşme Okulunun Bütünleştirici Çerçevesi. Akdeniz University Journal of Faculty of Economics and Administrative Sciences, 3(6), 73-122.

Schnell, M. C. A. (2003). Does the Effectiveness of Airline Strategies Change? A Survey of European Full Service Airlines. International Journal of Transport Management, 1(4), 217-224. http://dx.doi.org/10.1016/j.ijtm.2004.02.001

Sheth, J. N., Allvine, F. C., Uslay, C., \& Dixit, A. (2007). Deregulation and Competition: Lessons from the Airline Industry. New Delhi: Response Books.

Sinha, D. (2001). Deregulation and Liberalisation of the Airline Industry. Aldershot: Ashgate.

Stigler, G. J. (1971). The Theory of Economic Regulation. The Bell Journal of Economics and Management Science, 2(1), 3-21.

Stragier, J. (2001). Airline Alliances and Mergers - The Emerging Commission Policy. European Air Law Association, November, Zurich. [Online] Available: http://ec.europa.eu/competition/speeches/text/sp2001_040_en.pdf

Şengür, Y., \& Kuyucak, F. (2009). Havayolu Endüstrisinde Rekabet Avantajı Yaratmada Bilgi Teknolojileri Kullanımı. 7th International Conference on Knowledge, Economy and Management Proceedings. Yalova, Turkey. pp. 1854-1860.

Şengür, Y. (2004). Havayolu Taşımacılığında Düşük Maliyetli Taşıyıcılar ve Türkiye'deki Uygulamalarının Araştırılması. (Unpublished master dissertation). Anadolu University/Graduate School of Social Sciences, Eskisehir.

Torlak, N. G. (2008). Organizasyon Teorileri. İstanbul: Beta.

Ülgen, H., \& Mirze, S. K. (2007). İşletmelerde Stratejik Yönetim. (4th ed.). İstanbul: Arıkan.

Wensveen, J. G. (2007). Air Transportation: A Management Perspective. (6th ed.). Aldershot: Ashgate.

Williams, G. (2002). Airline Competition: Deregulation's Mixed Legacy. Aldershot: Ashgate.

Wilson, J. B. (1990). The Lessons of Airline Deregulation and the Challenge of Foreign Ownership of U.S. Air Carriers. George Washington Journal of International Law and Economics, 24(1), 103-147.

Yıldırım, A., \& Şimşek, H. (2008). Sosyal Bilimlerde Nitel Araştırma Yöntemleri. Ankara: Seçkin.

Yüksel, Ö. (2007). Insan Kaynakları Yönetimi. (6th ed.) Ankara: Gazi.

\section{Copyright Disclaimer}

Copyright reserved by the author(s).

This article is an open-access article distributed under the terms and conditions of the Creative Commons Attribution license (http://creativecommons.org/licenses/by/3.0/). 